\title{
Variations of surface water quality in selected tidal creeks of Sagar Island, Indian Sundarban eco-region: a multivariate approach
}

\author{
Sanghamitra Basu ${ }^{1} \cdot$ Subarna Bhattacharyya ${ }^{1} \cdot$ Pranab Gogoi $^{2} \cdot$ Suryasis Dasgupta ${ }^{1} \cdot$ Sanjoy Kumar Das $^{2}$
}

Received: 26 November 2019 / Accepted: 3 March 2021 / Published online: 24 March 2021

(c) The Author(s) 2021

\begin{abstract}
Sagar Island in Indian Sundarbans is bestowed with numerous tidal creeks providing a suitable home to its inherent aquatic biota. The present study investigated the variation in the surface water quality in selected tidal creeks of Sagar Island, Indian Sundarbans to understand the present status of water quality for wildlife propagation and fisheries. Ten water parameters were taken into consideration for analysis on monthly basis from four stations (tidal creeks) from September 2015 to August 2016. One-way ANOVA showed five parameters (water temperature, salinity, dissolved oxygen, turbidity and chemical oxygen demand) varied significantly between seasons $(p \leq 0.05)$. Factor analysis exhibited four factors explaining $53.21 \%$ total variance in the observed data. Salinity and turbidity showed a maximum annual range of variations followed by dissolved oxygen. The fluctuations of physicochemical parameters throughout the year hinted toward the ever-changing nature of the estuarine ecosystem with possible human-induced impacts. Pronounced variation in turbidity seemed to be the effect of ferrying/transportation, monsoonal runoff and other human-induced activities. In the present study, water parameters viz., water temperature, dissolved oxygen and turbidity were the deterministic parameters influencing the variables in the system. The other important parameters were found to be $\mathrm{COD}, \mathrm{BOD}_{3}$ and nitrate concentrations during the study period. The study shall provide baseline information in formulating the management measures in terms of water quality in wildlife propagation and fisheries.
\end{abstract}

Keywords Water parameters $\cdot$ Creeks $\cdot$ Multivariate approach $\cdot$ Sundarbans

\section{Introduction}

Sundarbans, the largest deltaic stretch of mangrove forest in the world, is formed at the estuarine phase of the GangesBrahmaputra river system (Chaudhuri et al. 2012). The area of Sundarbans is characterized by a low flat alluvial plain covered with mangrove swamps and marshes, and it is crisscrossed by a large number of tidal rivers, estuaries, creeks and saline water courses (Bagchi 1972). The biodiversity of Indian Sundarbans is extremely rich and also consists of extremely rich coastal, estuarine and marine fisheries. Taking this into consideration, it has been declared as world

Sanghamitra Basu

oomphsenorita090@gmail.com

1 School of Environmental Studies, Jadavpur University, Kolkata 700032, India

2 Kolkata Centre, ICAR-Central Inland Fisheries Research Institute, C.G.O. Complex, 2nd Floor, Sector-1, Kolkata, West Bengal 700 064, India heritage site by United Nations Educational, Scientific and Cultural Organization (1987) which shall go a long way to protect and conserve biodiversity (Sreelekshmi et al. 2020). Recently, in February 2019, the Indian Sundarbans has also been designated as 'Wetland of International Importance' (Ramsar site) (Sreelekshmi et al. 2020). Gopal and Chauhan (2006) stated the extensive spatiotemporal changes in hydrological regimes, topography and texture of the substratum, salinity and their interactions cause habitat heterogeneity in the mangrove ecosystems which affects the aquatic vegetation and fauna directly, and also causing damage especially to the seabirds. The author also stated that there is continuous threat to biodiversity due to the burgeoning human population, pollution, growing industrialization, oil spills, oil exploration, global climate change and sea level rise.

Tidal creeks are extremely abundant in Sundarbans estuarine systems which serve as feeder rivers, providing food control, storm water drainage and habitat to wildlife. It is ecologically important for the transfer of materials from terrestrial to marine biome, habitat to nursery ground for 
commercial fisheries (Mallin and Lewitus 2004; Saliu and Ekpo 2006). There has been a considerable loss of creeks due to overuse, pollution, diversion, land filling, etc., and Indian Sundarbans is also not an exception thereof. The nature and distribution of biodiversity are primarily ruled by variations in the physicochemical properties of water (Murugan and Ayyakkannu 1991). It is also responsible for supporting aquatic life and maintaining the aquatic environment and is likely to have an impact on the growth of the organisms as well as the productivity of the ecosystems (Das 2012). The physicochemical properties of the estuarine environment are highly dynamic due to the influx of fresh water. Surface waters are the most vulnerable and are exposed to rapid pollution due to their easy accessibility both the natural and anthropogenic causes (Singh et al. 2004; Barakat et al. 2016). These creeks are also acting as the probable channels for carrying pollutants (municipal and industrial wastes run off from agricultural land) to the estuarine core. Barletta et al. (2019) opined that the estuaries are often found to have the hard-hit zones with respect to the heavy metals and pesticides, and usually it has a high residence time for pollutants. In addition, the seasonal variation of precipitation, surface runoff, is a seasonal phenomenon which also supports to constitute the polluting source, largely affected by climate. Since estuaries and the supported creeks are highly fecund ecosystems and provides congenial home for the inherent biota, it is necessary to prevent and control the sources of pollution and to have reliable information on quality of water for effective management. Therefore, it is imperative to understand the changes in water quality variables from time to time for the quality assessment of the ecosystem (Chang 2008). The gradual increase in human activities for developing coastal areas also have resulted in loss of ecological values of the tidal creeks (Vernberg and Vernberg 2001). The large variability in hydrological parameters in coastal water influences, topographic heterogeneity and their interactions, has resulted in a biodiversity explosion in the Sundarbans mangrove eco-region (Ansari et al. 2017). Although such creek ecosystems are highly vulnerable to environmental changes and anthropogenic interferences, yet their ecological significance is underestimated as very less studies on these systems have been so far conducted relative to larger, better-known estuarine systems (Mallin and Lewitus 2004). Therefore, the present study evaluated the water quality status of four creeks (Costala, Gangasagar, Chemaguri and Mooriganga) in the Sundarban eco-region. Reports are available on fluctuations of physicochemical parameters in various parts of Sundarbans (Sarkar et al. 1986; Mitra et al. 2009; Manna et al. 2010; Das 2012; Chaudhury et al. 2012; Rakshit et al. 2015); however, the studies on spatiotemporal variations of water quality in tidal creeks, at Sagar Island are still scarce. The island had been affected by natural coastal processes, storm waves and artificial constructions such as seawalls and jetties, etc. (Mondal et al. 2017). The effects of climate change are also well documented in and around Sagar Island (Mitra et al. 2009).

The multivariate statistical approaches have become popular in recent times due to their ability to treat large volume of spatial and temporal data from variety of monitoring sites (Barakat et al. 2016). Different multivariate statistical techniques such as cluster analysis, principal component analysis, factor analysis and discriminant analysis are used to interpret the complex data matrices for a better understanding of the water quality and ecological status of the studied ecosystems (Vega et al. 1998; Noorie et al. 2010; Wang et al. 2014). It also allows the identification of possible factors that have an impact on water systems and provides an essential tool for reliable management of water resources (Wunderlin et al. 2001; Reghunath et al. 2002; Simeonova et al. 2003). Helena et al. (2000) stated that multivariate statistical techniques facilitate to characterize and evaluation of surface water quality, which will be useful further in verifying spatial and temporal patterns linked to seasonality. Wang et al. (2007) evaluated the spatiotemporal variations of water quality of 19 rivers by applying the cluster analysis and factor analysis. Similarly, Kumarasamy et al. (2014) and Khan et al. (2016) applied cluster analysis and factor analysis to investigate the variability of hydrochemistry from Tamrapani river, Southern India and Ramganga river (Ganga basin), respectively. The correlation analysis, principal component analysis and canonical correlation components were used by Noori et al. (2010) to study the seasonal variation of water variables, relationship between physical and chemical parameters and selection of principal and non-principal monitoring stations in the Karoon river basin, Iran. Sharma et al. (2015) also applied former multivariate techniques to identify the potential sources of pollution and clustering of monitoring stations of Ganga and Yamuna River in Uttarakhand, India. Furthermore, usefulness of cluster analysis, principal component analysis and factor analysis for interpreting the complex data sets, identifying the attributes responsible for pollution as well as water quality management previously reported by several workers (Shreshtha and Kazma 2007; Noori et al. 2010, 2012; Wang et al. 2012, 2014; López-López et al. 2014; Bostanmaneshrad et al. 2018). In the recent times, several authors have evaluated the underlying relationship between macro-scale parameters (land use, population density, geology, erosion, etc.) with the micro-scale attributes, i.e., water quality parameters (Bostanmaneshrad et al. 2018; Chimwanza et al. 2014; Liu et al. 2016). Bostanmaneshrad et al. (2018) quantified the significant relationship between land use and phosphorus, total solids and turbidity, erosion levels and electrical conductivity, and erosion and total solids in their study from Siminehrood river basin. All the previous studies showed that the multivariate statistical methods are 
important tools to determine the relationships between the water quality parameters, and identify particular attributes responsible for the relationship. With this view, the present study is an attempt to understand the present ecological health and status of tidal creeks in the mangrove ecosystems of Sagar Island by approaching multivariate techniques. The basic objective of the study is to evaluate the spatiotemporal variability in physicochemical parameters of surface water samples collected from the selected tidal creeks.

\section{Study area}

Sagar Island (between latitude $21^{\circ} 37^{\prime}$ and $21^{\circ} 52^{\prime} \mathrm{N}$ and longitude $88^{\circ} 03^{\prime}$ and $88^{\circ} 11^{\prime} \mathrm{E}$ ), part of the Hooghly-Matlah estuary is subjected to intense tidal and wave actions (Majumdar et al. 2002). The island has unique mangrove vegetation and surrounded by the river Hooghly on the north and the west, Mooriganga on the eastern side, while the southern part faces the Bay of Bengal. The island is inundated by various natural tidal creeks and artificial canals which are a source of saline surface water in the island (Chakraborty 1995). The island experiences a semidiurnal tidal regime with high tide zone ranges from 5 to $6 \mathrm{~m}$ (Paul and Bandhopadhay 1987). The island is also highly vulnerable to environmental degradations, burgeoning population and erosion which accounted for approximately $30 \mathrm{~km}^{2}$ net land loss in the last three decades (Hazra et al. 2002). Among the tidal creek system at Sagar, Chemaguri creek is the most prominent one with planted mangroves along its length (Mitra et al. 2009). The present study was carried out from September 2015 to August 2016 in 4 (four) major creeks viz. Costala $\left(21^{\circ} 48^{\prime} 829^{\prime \prime} \mathrm{N} 88^{\circ} 09^{\prime} 93^{\prime \prime} \mathrm{E}\right)$,

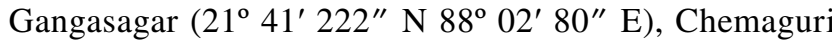
( $\left.21^{\circ} 40^{\prime} 745^{\prime \prime} \mathrm{N} 88^{\circ} 07^{\prime} 695^{\prime \prime} \mathrm{E}\right)$ and Mooriganga $\left(21^{\circ} 48^{\prime} 828^{\prime \prime} \mathrm{N} 88^{\circ} 09^{\prime} 93^{\prime \prime} \mathrm{E}\right.$ ) (herein referred as S1, S2, S3 and S4, respectively) at Sagar Island, Indian Sundarbans. The sampling sites were designed to cover a wide range of determinants of key sites, which reasonably represent the water quality of the creeks in the Island. The sites were selected mainly based on their mangrove vegetation covers and also ranging from region with high riverine influence (Costala and Mooriganga) to brackish water regions and mangrove vegetation (Chemaguri and Gangasagar). The geographical locations of the sampling sites and study area in Sagar Island, Sundarbans are shown in Fig. 1.

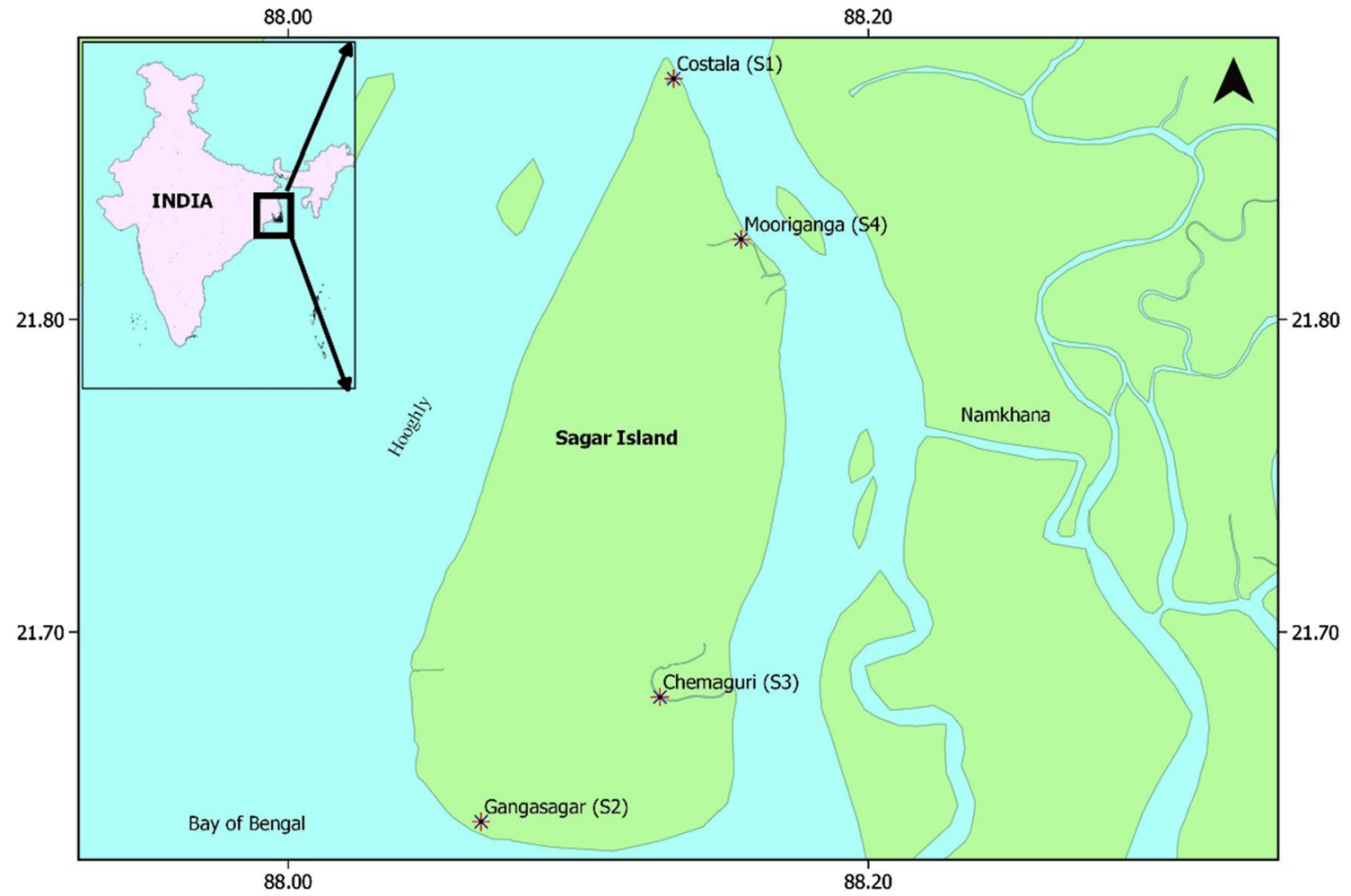

Fig. 1 The map showing the geographical locations of the sampling sites and study area in Sagar Island, Sundarban 


\section{Sampling procedure}

Surface water samples were collected in pre-cleaned acid washed polyethylene bottles $(1.0 \mathrm{~L})$ during low tide before noon from the selected locations. Water temperature (WT) was measured on field by using a mercury thermometer $\left(0-100{ }^{\circ} \mathrm{C}\right)$; $\mathrm{pH}$ with a digital pH meter (Model No. $101 \mathrm{E}$ ), and turbidity (Nephelometric turbidity unit) was measured by a turbidity meter (Model No. EI 331E). The in situ estimation of dissolved oxygen (DO) and salinity (ppt) was done by the titrimetric method (APHA 2005). Collected water samples were brought to the laboratory in cold conditions for nutrient analysis. Nutrients such as nitrate, phosphate and silicate were analyzed following standard methods described in APHA (2005). For analysis of chemical oxygen demand (COD) and biochemical oxygen demand (BOD), water samples were collected separately in $500 \mathrm{ml}$ polyethylene bottles. COD was measured by the open reflux method, and BOD was estimated by a 3-days BOD incubation $\left(\mathrm{BOD}_{3}\right)(\mathrm{APHA}$ 2005). All the methods were standardized as per ambient conditions and blank measurements were taken into consideration for the estimation procedures. HPLC grade water was used throughout the laboratory works. Since determination of $\mathrm{BOD}\left(\mathrm{BOD}_{3}\right.$ and/or $\left.\mathrm{BOD}_{5}\right)$ is a long-time estimation process, several attempts have been made to shorten the process by applying alternate analytical methods (Noori et al. 2011, 2013). The analytical model such as reduced-order neural network model (RONNM) and reduced-order adaptive neuro-fuzzy inference system (ROANFIS) model fed with input vectors [latitude $(\mathrm{N})$, longitude $(\mathrm{E})$, suspended solids, water temperature, river discharge, DO, electrical conductivity, nitrate and total phosphorus] is developed which indicated the best fitted online predictions of $\mathrm{BOD}_{5}$ (Noori et al. 2011, 2013).

\section{Data treatment}

Statistical computations such as one-way ANOVA, Pearson correlation, clustering dendrogram and factor analysis were performed with the help of software applications (SPSS v. 23 and XLSTAT v. 2018). The environmental data were normalized by transforming $\log (x+1)$ prior to analysis. The water quality parameters of different seasons were subjected to one-way analysis of variance (ANOVA) and Duncan's multiple range tests (DMRT) post-hoc test using SPSS v.23. The post-hoc test was carried out to find out the significant variations of measured water variables between seasons. Pearson correlation (2-tailed) was conducted to comprehend the interdependence among the physicochemical parameters. This minimizes the effect of between stations correlations and between sampling campaigns relationships (Barakat et al. 2016). Further, the correlation coefficient -1 or 1 indicated the strongly negative or positive relationship between the two variables, whereas its value closer to 0 defined no linear relationship between them at 0.05 significance level (Kumar et al. 2006; Barakat et al. 2016). Hierarchical agglomerative cluster analysis was performed to understand a measure of similarity using Euclidean distances (Zhao et al. 2011; Singh et al. 2004; Sharma 1996). The hierarchical cluster analysis is the most common approach where the clusters are formed based on the similar nature attributes and forming higher clusters step-by-step (Willet 1987). Generally, the Euclidean distance portrayed the proximity between two samples and 'distance' which is represented by the 'difference' between the obtained values from both the samples (Otto 1998), and it is illustrated through a dendogram (Forina et al. 2002). Further, nonmetric dimensional scaling (NMDS) was also performed to visualize the dimensions to understand the similarity or dissimilarities among data sets. Likewise, factor analysis was performed (XLSTAT v.18) on the water quality data to find out the factors related to influence each of them. The first step of factor analysis is to standardize the raw data and make them dimensionless. The correlation coefficient matrix, eigen values and eigen vectors were determined to yield the covariance matrix (Wang et al. 2014). The factors with eigen values that exceed 0.5 were considered in this study, whereas only three factors obtained that exceed one. Varimax rotation is an important second step in factor analysis used for maximizing the sum of the variance of the squared loadings, where 'loadings' means correlations between variables and factors. The varimax rotation on the factor loading infers the rotated principal factors (Singh et al. 2004, 2012; Noori et al. 2010; Ghahremanzadeh et al. 2018).

Table 1 Seasonal variation of water quality parameters in the study sites of Sundarbans

\begin{tabular}{lccc}
\hline Water variables & Pre-monsoon & Monsoon & Post-monsoon \\
\hline pH & $7.67^{\mathrm{a}} \pm 0.29$ & $7.65^{\mathrm{a}} \pm 0.52$ & $7.50^{\mathrm{a}} \pm 0.50$ \\
Water temperature & $27.67^{\mathrm{a}} \pm 3.00$ & $26.29^{\mathrm{a}} \pm 3.07$ & $20.88^{\mathrm{b}} \pm 0.97$ \\
$\quad\left({ }^{\circ} \mathrm{C}\right)$ & \multicolumn{4}{c}{} \\
Salinity (ppt) & $25.59^{\mathrm{a}} \pm 6.105 .83^{\mathrm{b}} \pm 6.82$ & $13.54^{\mathrm{c}} \pm 5.74$ \\
Dissolved oxygen & $5.97^{\mathrm{a}} \pm 1.32$ & $5.96^{\mathrm{a}} \pm 1.57$ & $4.69^{\mathrm{b}} \pm 0.83$ \\
$\quad\left(\mathrm{mgl}^{-1}\right)$ & \multicolumn{4}{c}{} \\
Turbidity $(\mathrm{NTU})$ & $43^{\mathrm{a}} \pm 22.83$ & $65^{\mathrm{b}} \pm 18.1136 .93^{\mathrm{a}} \pm 28.78$ \\
Phosphate $\left(\mathrm{mgl} l^{-1}\right)$ & $2.64^{\mathrm{a}} \pm 2.39$ & $2.90^{\mathrm{a}} \pm 4.47$ & $4.0^{\mathrm{a}} \pm 3.35$ \\
Nitrate $\left(\mathrm{mgl}^{-1}\right)$ & $1.29^{\mathrm{a}} \pm 0.73$ & $1.40^{\mathrm{a}} \pm 0.65$ & $1.10^{\mathrm{a}} \pm 0.57$ \\
Silicate $\left(\mathrm{mgl}^{-1}\right)$ & $12.94^{\mathrm{a}} \pm 7.26$ & $16.6^{\mathrm{a}} \pm 7.97$ & $13.18^{\mathrm{a}} \pm 6.30$ \\
$\mathrm{COD}\left(\mathrm{mgl}^{-1}\right)$ & $23.93^{\mathrm{a}} \pm 8.39$ & $17.87^{\mathrm{b}} \pm 6.09$ & $17.0^{\mathrm{b}} \pm 4.03$ \\
$\mathrm{BOD}_{3}\left(\mathrm{mgl}^{-1}\right)$ & $2.20^{\mathrm{a}} \pm 0.77$ & $1.86^{\mathrm{a}} \pm 0.67$ & $1.81^{\mathrm{a}} \pm 0.49$ \\
\hline
\end{tabular}

Values are means \pm SE means followed by the same letter are not significantly different at $5 \%$ probability level 


\section{Results and discussion}

The variation of water quality parameters in different seasons (pre-monsoon, monsoon and post-monsoon) is documented in Table 1. One-way ANOVA showed that, out of ten parameters, five parameters (WT, salinity, DO, turbidity and COD) varied significantly between the seasons $(p \leq 0.05)$. The water remained neutral to alkaline throughout the study period well within the predicted range between 7.36 and 8.16. The result is in agreement with the findings of Manna et al. (2010) and Choudhury et al. (2012) from Sundarban waters. The rate of photosynthesis process, which removes $\mathrm{CO}_{2}$ from water through bicarbonate degradation, freshwater influx and decomposition of organic matter, could have contributed to the fluctuation of $\mathrm{pH}$ (Rahman et al. 2013). The alkaline nature of water $(\mathrm{pH}>7.0)$ with low variations between the sampling stations, suggested that the water mass remained well buffered throughout the study period, and it indicated the presence of biodegradable organic matter in the water column. Surface water temperature varied significantly $(p \leq 0.05)$ from post-monsoon to pre-monsoon. Water temperature of the tidal creeks showed a forecasted range of variability with lowest in post-monsoon in the month of January $\left(19.34{ }^{\circ} \mathrm{C}\right)$, and had a maximum in pre-monsoon in the month of June $\left(31.13^{\circ} \mathrm{C}\right)$. In tidal influenced estuarine environment of the Sundarbans, temperature values undergo a wide diurnal and seasonal variation. A gradual increase in salinity was observed from post-monsoon to pre-monsoon, recorded maximum in May (28.08 ppt) and lowest in October $(0.79 \mathrm{ppt})$. The distinct temporal variation of salinity in the present study was similar to Saravanakumar et al. (2008); Choudhury et al. (2012) and Gogoi et al. (2019). Saravankumar et al. (2008) stated that low salinity level in brackish water habitats such as backwaters, estuaries and mangrove waters is due to influx of freshwater from land runoff caused by precipitations or by tidal variations, which supported our present findings. Manna et al. (2010) also reported similar findings with the lower salinity during winter months (November-February; avg. 16.7 PSU) as compared to summer months (March to May; 23.5 PSU) from Bara Herobhanga Khal (Jharkhali waters), Sundarbans. Moderate concentrations of dissolved oxygen were recorded across the stations with its maximum in October at the station Chemaguri $\left(7.8 \mathrm{mgl}^{-1}\right)$ and minimum in December at Mooriganga $\left(3.29 \mathrm{mgl}^{-1}\right.$ ). Dissolved oxygen and water temperature were influenced to a greater extent by atmospheric conditions and sampling times (Debels et al. 2005); as a result, its concentrations vary during various moments of the day and under different weather conditions. Lower concentrations of DO during post-monsoon may be due to increased salinity, temperature and biological activity (Levinton 2001). Our observation is in conformity with Sarkar and Bhattacharya (2010) where the authors stated that dissolved oxygen concentration in the surface water of Sundarbans mangrove wetland ranged from 5.18 to $6.49 \mathrm{mgl}^{-1}$ with an average value $4.0 \mathrm{mgl}^{-1}$, indicating that surface waters are moderately oxygenated. Turbidity was recorded in the expected level with its peak during monsoon which might be due to riverine influx bearing excess suspended load coupled with high monsoon precipitations. The steady expansion of waterway transportation/vessel trafficking was also one of the reasons for the enhancement of turbidity at the stations under study. The mean value of turbidity was highest at Chemaguri in the month of November and the lowest at Gangasagar in December. The observed range of COD was $8.0-40.0 \mathrm{mgl}^{-1}$ across the stations with an average value $19.60 \pm 7.0 \mathrm{mgl}^{-1}$, which exceeds the permissible range of World Health Organization, i.e., $<10 \mathrm{mgl}^{-1}$. The precipitation causes dilution during monsoon which could be the reason for lower concentration of COD during monsoon. The moderate concentration of COD in the present study was indicating toward pollution of the aquatic ecosystem due to natural and anthropogenic stresses. Bhattacharya et al. (2015) reported high range of COD values $\left(101.28-111.31 \mathrm{mgl}^{-1}\right)$ in their studies from Jambu Island, Sundarbans and stated that it is derived from the primary production of the dense mangrove forests. High COD values in a tropical coastal wetland in Southern Mexico were also previously reported by Hernández-Romero et al. (2004), and it was associated with mangrove-enriched organic matters which supported the present findings. The $\mathrm{BOD}_{3}$ ranges between 1.62 and $2.23 \mathrm{mgl}^{-1}$ with an average $1.96 \mathrm{mgl}^{-1}$, where maximum and minimum were recorded at Gangasagar and Mooriganga, respectively. An average value of 2.04 $\mathrm{mgl}^{-1}$ BOD was reported previously by Rahman et al. (2015) from Sundarban waters, Bangladesh which is in line with our present observations.

Non-uniform seasonal trend for nutrients was observed throughout the study period. In general, nutrients are sufficient to support primary productivity in an estuarine environment. Tidal fluctuation is the main driving force for the distribution of nutrients in Indian Sundarbans, where its dispersion primarily depends on the tidal motions of the water body (Chaudhuri et al. 2012). No significant $(p \geq 0.05)$ variations of nutrients (phosphate, nitrate and silicate) were observed across the seasons. Phosphate concentration was estimated to be highest at station Mooriganga $\left(11.7 \mathrm{mgl}^{-1}\right)$ in the month of October while the lowest at Gangasagar $\left(0.4 \mathrm{mgl}^{-1}\right)$ in March. Lower concentration of phosphate during pre-monsoon season might be due to its utilization by photoautotrophs, and buffering actions of sediments in various environmental conditions (Rajasegar 2003). Silicate and nitrate showed higher concentration in monsoon as compared to post-monsoon and pre-monsoon during the study period. Higher values of nitrate and silicate in monsoon may 
be attributed to freshwater influx and land runoff (Sathpathy et al. 2009; Ramakrishnan et al. 1999). Similarly, Karuppasamy and Perumal (2000) stated that higher magnitude of nitrate during monsoon might be caused by the organic matter being enriched by the monsoonal flow and decomposition of terrestrial runoff from the catchment areas. Sarkar and Bhattacharya (2010) also opined that land-based nutrients, especially from the agricultural fields in proximity, contributed to a greater extent to the enrichment of nutrient concentrations during monsoon. The inverse trend was observed with regard to phosphate concentrations that recorded the maximum during post-monsoon. Silicate values were found to be relatively higher as compared to the nitrate and phosphate in the present study, which is in line with Vajravelu et al. (2018). Maximum concentration of nitrate and silicate was observed in the month of October $\left(3.20 \mathrm{mgl}^{-1}\right.$; at Chemaguri) and August (31.7 $\mathrm{mgl}^{-1}$ at Costala), and lowest in the month of April $\left(0.62 \mathrm{mgl}^{-1}\right.$ at Gangasagar) and March (4.24 mgl ${ }^{-1}$ at Chemaguri), respectively. The high silicate and phosphate ratio $(\mathrm{Si}: \mathrm{P})$ in the present study is corroborated with the findings of Chaudhuri et al. (2012) and Sarkar and Bhattacharya (2010). However, the Si:P ratio was somewhat lower than 'modified' Redfield ratio (15:1) (Brzezinski 1958), and our present observations in seasonal estimates of silicate indicated broad seasonal fluctuations in the creek environment. Similarly, Choudhury and Bhadury (2015) reported that seasonal estimates of N:P ratio remained below the Redfield ratio (16:1), indicated nutrient limited (nitrogen) environment in Sagar island which is in line with our present observation from Sagar Island. Arumugum et al. (2016) also showed low N:P ratio than the Redfield ratio in Muthupet mangrove waters depicted a low bio-availability of nitrogen for primary production which confirms to our estimates. Redfield (1958) approached to a conclusion that atomic ratios of elements in the biochemical cycle of plankton were statistically uniform and follow the stoichiometric ratio of $\mathrm{C}: \mathrm{N}: \mathrm{P}=106: 16: 1$ and this variation

Table 2 Nutrient parameters: nitrate, phosphate and silicate $(\mathrm{N}: \mathrm{P}: \mathrm{Si})$ ratio in the study sites of Sundarbans

\begin{tabular}{lll}
\hline Months & N:P & Si:P \\
\hline September & 0.29 & 2.10 \\
October & 0.27 & 1.89 \\
November & 0.37 & 4.93 \\
December & 0.67 & 7.78 \\
January & 0.19 & 2.14 \\
February & 1.14 & 6.45 \\
March & 0.95 & 4.98 \\
April & 0.37 & 2.26 \\
May & 0.48 & 5.59 \\
June & 0.45 & 8.76 \\
July & 0.44 & 7.34 \\
August & 0.55 & 8.90 \\
\hline
\end{tabular}

is mainly due to synthesis or decomposition of organic matter. The estimated ratio of nitrate, phosphate and silicate is shown in Table 2.

Intra-relationship of various environmental variables (Karl Pearson's correlation coefficient) showed significant positive correlation of water temperature with salinity $(r=0.42 ; p \leq 0.01), \mathrm{DO}(r=0.55 ; p \leq 0.01)$, silicate $(r=0.40$; $p \leq 0.01)$; COD $(r=0.38, p \leq 0.01)$, and it was negatively correlated with phosphate $(\mathrm{r}=-0.11)$. According to Osibanjo et al. (2011) and Şener et al. (2017), one very common but essential parameter, $\mathrm{pH}$ governs various other parameters like alkalinity, solubility and also the hardness. The $\mathrm{pH}$ had significant positive correlation with DO $(r=0.31 ; p \leq 0.05)$. Similar observation was also reported by Gogoi et al. (2019) in their study from Kailash Khal, Sundarbans; depicted that $\mathrm{pH}$ had a positive correlation with water temperature and also salinity with the water temperature and DO. The strong positive correlation was observed between salinity and COD $(r=0.39 p \leq 0.01)$, and nutrients such as nitrate $(r=0.35$ $p \leq 0.01)$ and silicate $(r=0.41 p \leq 0.01)$. Gogoi et al. (2020) also found similar observation in their study from Sundarban waters, where salinity had a positive correlation with the nutrient parameters (phosphate, silicate and sulfate).

\section{Multivariate approach}

Cluster analysis was performed season-wise to understand the percentage similarity among various stations. The hierarchical group average showed the variations in water parameters by clustering similar nature of samples/sampling stations. It formed two clusters with the maximum similarity between the stations Chemaguri and Costala during premonsoon, while showed maximum dissimilarity between the station Chemaguri during monsoon and Gangasagar during pre-monsoon (Fig. 2). The freshwater influx with its high allochthonous inputs during the rainy season also could be a reason for variations of water attributes during monsoon. Further, NMDS also showed the similar nature of ordinance pattern among samples/sampling stations that were observed in cluster analysis (Fig. 3). The stress value was found less than 0.14 which is good ordinance pattern that distance among items/samples are perfect. In this study, water parameters such as dissolved oxygen and turbidity were found to be strong parameters influencing their variables in the system. The other important parameters were found to be COD, $\mathrm{BOD}_{3}$ and phosphate concentrations during the study period (Table 3).

Results of the factor analysis showed, four factors were extracted which explained $53.21 \%$ of the total variance in the observed data (Table 4 and Fig. 4). The eigen value and cumulative percentage variability of the extracted factor from the data set are shown in the scree plot (Fig. 5). Factor 1 accounts for $22.62 \%$ variance where the parameters 


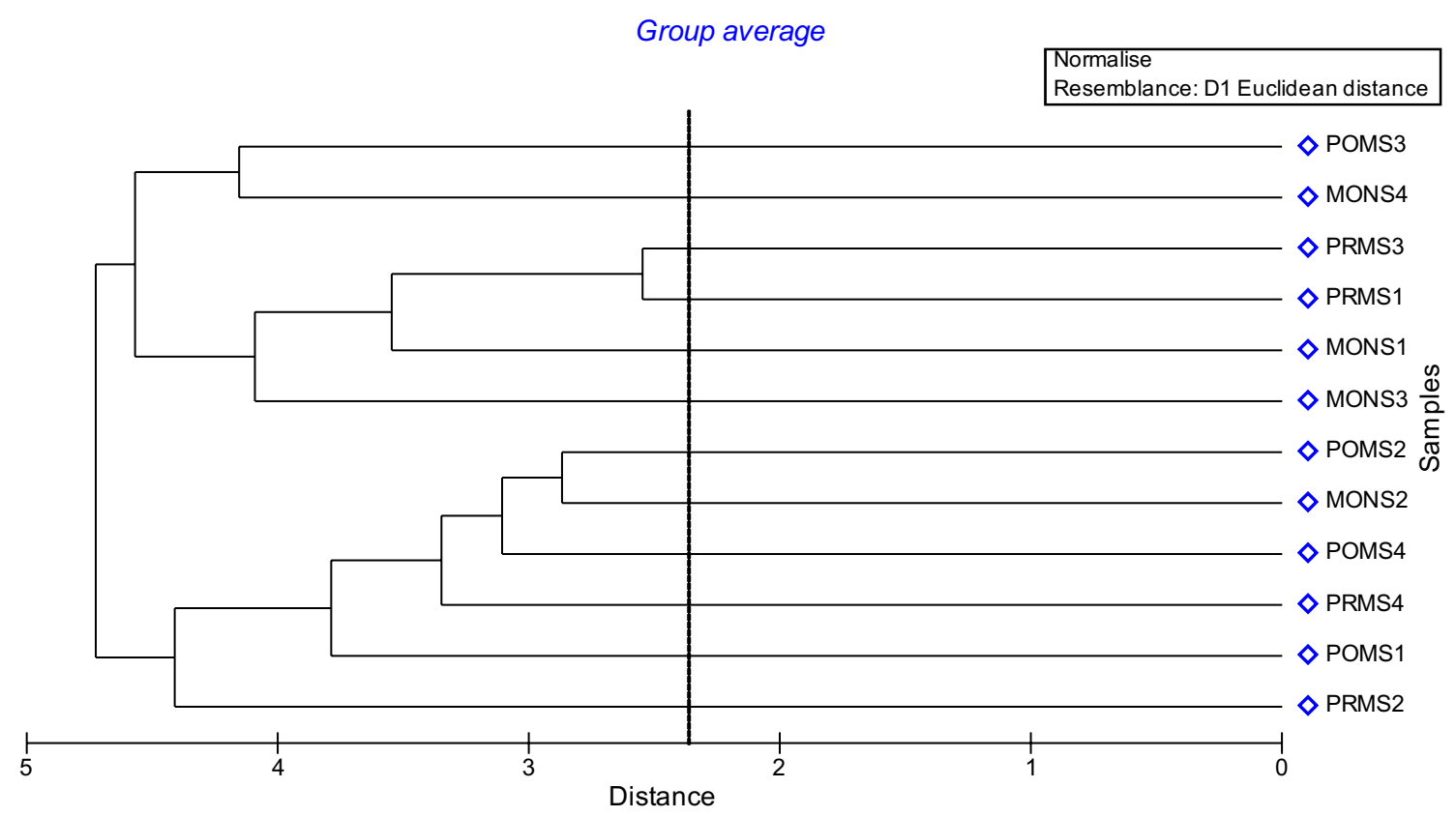

Fig. 2 Dendogram showing the similarity of stations in seasons

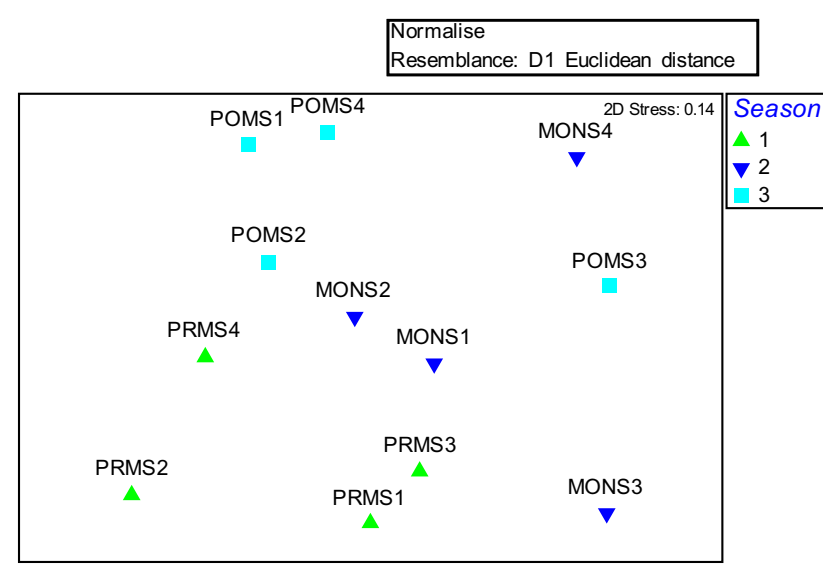

Fig. 3 NMDS showing the environmental variables recorded in various stations and seasons (1: pre-monsoon; 2: monsoon; 3: post-monsoon)

(loadings) such as $\mathrm{pH}, \mathrm{WT}$, salinity, DO, silicate and COD were positively correlated, while the attributes viz., turbidity, phosphate and nitrate were negatively correlated. Similar observations also reported by Sarkar and Bhattacharya (2010), where they stated that, the factors appear (negative correlation of nitrate, phosphate and BOD) to be originated from the combined effect from the anthropogenic activities. Factor 2 explained the $15.88 \%$ total variance, and it was negatively loaded with variables; DO, turbidity and nitrate. The causes may be due to gradual increase in water transportation/fishing vessels and agriculture expansions. Likewise, factor 4 represents the $6.68 \%$ total variance. The factor loading revealed that parameters such as phosphate, $\mathrm{COD}$ and $\mathrm{BOD}_{3}$ were negatively correlated with each other. Since these causes of these parameters (phosphate and COD) are primarily from the source of agricultural land and industrial activities. BOD represents the high organic load, which enriching the growth of microorganisms in the mangrove patches. From this analysis, it is reflected that the major causes of the water quality variations/degradation seemed to be more usage of nitrogenous and phosphate-rich fertilizers, discharge of untreated industrial effluents, increasing waterway transportation which accelerates the oil spills in river/estuary and also the other non-point sources. With the best uses of Sundarban waters in different aspects such as fishing, irrigation, ferry service, boating and tourism, some water quality parameters are still well within the permissible limits, where it is seemed to be suitable for bathing, aquatic biodiversity, fisheries and recreation, etc., according to the criterion placed from the various best designated use prescribed by the World Health Organization, US Environmental Protection Agency and Pollution Control Board, India (Table 5).

\section{Conclusion}

The present study reflected the changes in some important hydrological factors round the year which hinted toward the dynamic nature of the estuarine ecosystem due to climate change and human-induced impacts. Salinity and turbidity showed the maximum annual range of variation followed 
Table 3 Intra-relationship of environmental variables in Sundarbans

\begin{tabular}{lllllllllll}
\hline Variables & $\mathrm{pH}$ & WT & Sal & DO & Tur & Phos & Nitr & Si & COD & BOD $_{3}$ \\
\hline pH & 1 & & & & & & & & & \\
WT $\left({ }^{\circ} \mathrm{C}\right)$ & 0.15 & 1 & & & & & & & & \\
Sal $(\mathrm{ppt})$ & -0.04 & $0.42^{* *}$ & 1 & & & & & & & \\
DO $\left(\mathrm{mgl}^{-1}\right)$ & $0.31^{*}$ & $0.55^{* *}$ & 0.23 & 1 & & & & & & \\
Tur $\left(\mathrm{mgl}^{-1}\right)$ & 0.01 & 0.07 & $-0.36^{*}$ & 0.08 & 1 & & & & & \\
Phos $\left(\mathrm{mgl}^{-1}\right)$ & -0.03 & -0.11 & -0.18 & -0.22 & 0.13 & 1 & & & & \\
Nitr $\left(\mathrm{mgl}^{-1}\right)$ & 0.15 & 0.03 & -0.01 & $0.35^{*}$ & 0.24 & $0.28^{*}$ & 1 & & & \\
Si $\left(\mathrm{mgl}^{-1}\right)$ & 0.21 & $0.40^{* *}$ & 0.17 & $0.41^{* *}$ & 0.06 & -0.05 & -0.03 & 1 & & \\
$\mathrm{COD}_{(\mathrm{mgl}}-1$ & 0.12 & $0.38^{* *}$ & $0.39^{* *}$ & 0.18 & -0.24 & -0.02 & -0.25 & $0.31^{*}$ & 1 & \\
$\mathrm{BOD}_{3}\left(\mathrm{mgl}^{-1}\right)$ & 0.08 & 0.16 & 0.16 & -0.14 & -0.14 & -0.01 & -0.08 & -0.07 & $0.40^{* *}$ & 1
\end{tabular}

Sal salinity, Tur turbidity, Phos phosphate, Nitr nitrate, $\mathrm{Si}$ silicate

*Correlation is significant at the 0.05 level (2-tailed)

**Correlation is significant at the 0.01 level (2-tailed)
Table 4 Factor analysis of the water quality parameters after varimax rotation

\begin{tabular}{|c|c|c|c|c|}
\hline Variables & F1 & $\mathrm{F} 2$ & F3 & F4 \\
\hline $\mathrm{pH}$ & 0.2278 & -0.2161 & -0.1467 & -0.1480 \\
\hline WT $\left({ }^{\circ} \mathrm{C}\right)$ & 0.6762 & -0.1446 & -0.1032 & -0.0195 \\
\hline Salinity (ppt) & 0.7200 & 0.2571 & 0.5586 & 0.3216 \\
\hline $\mathrm{DO}\left(\mathrm{mgl}^{-1}\right)$ & 0.6617 & -0.5841 & -0.2197 & 0.1836 \\
\hline Turbidity $\left(\mathrm{mgl}^{-1}\right)$ & -0.1716 & -0.3797 & -0.1834 & -0.0815 \\
\hline Phosphate $\left(\mathrm{mgl}^{-1}\right)$ & -0.2117 & -0.1346 & 0.1579 & -0.3197 \\
\hline Nitrate $\left(\mathrm{mgl}^{-1}\right)$ & -0.0216 & -0.8382 & 0.4983 & -0.2208 \\
\hline Silicate $\left(\mathrm{mgl}^{-1}\right)$ & 0.4702 & -0.1529 & -0.2742 & -0.0090 \\
\hline $\mathrm{COD}\left(\mathrm{mgl}^{-1}\right)$ & 0.6732 & 0.3670 & -0.0626 & -0.4624 \\
\hline $\mathrm{BOD}_{3}\left(\mathrm{mgl}^{-1}\right)$ & 0.2128 & 0.2824 & 0.1310 & -0.3691 \\
\hline Variability (\%) & 22.6281 & 15.8826 & 8.0111 & 6.6847 \\
\hline Cumulative (\%) & 22.6281 & 38.5107 & 46.5218 & 53.2065 \\
\hline
\end{tabular}

Bold values indicating the highest loading for the variables

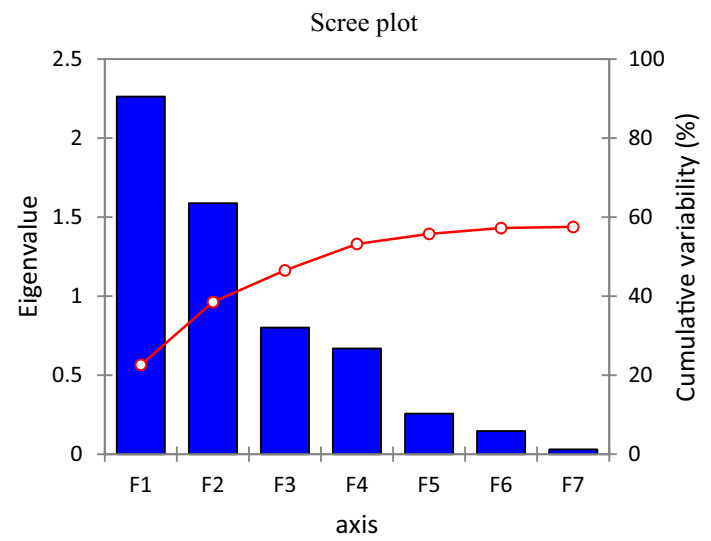

Fig. 4 Scree plot of the factor analysis after varimax rotation

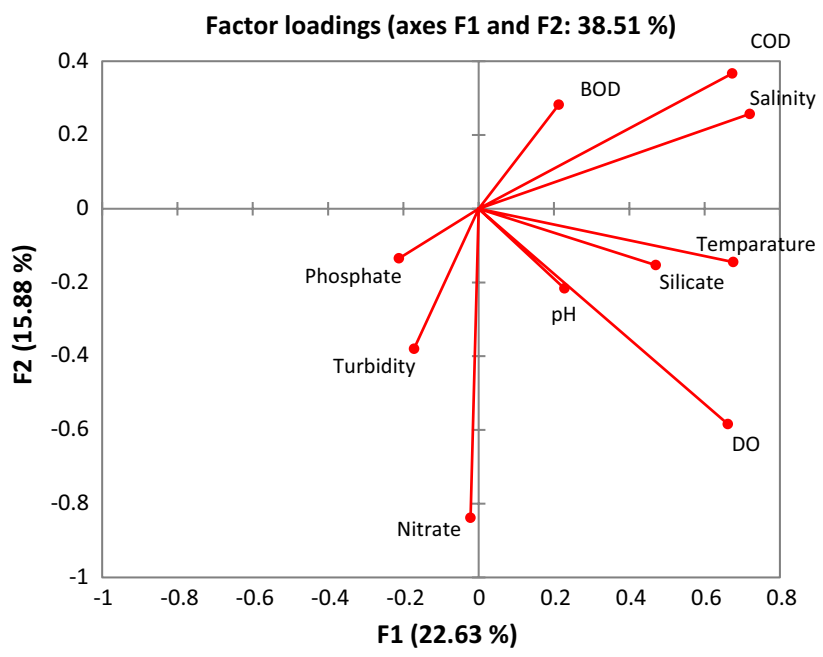

Fig. 5 Factor loading of water quality parameters after varimax rotation

by dissolved oxygen in the present study. Other parameters did not show any significant annual range of variation in the present study, though phosphate and COD values were higher in post-monsoon and pre-monsoon seasons, respectively. As there were no significant industrial activities in the near vicinity; therefore, the higher COD might be due to the presence of mangroves at sampling sites. Water variables such as dissolved oxygen, water temperature, salinity, turbidity and nitrate were the effective factors influencing their variables in the creeks, which was evident from factor analysis. The higher magnitude of COD in this study doesn't seem to indicate pollution in the study area. Higher turbidity seemed to be due to monsoonal runoff and ferrying activities in the creeks. Long-term monitoring approach is required to look for time-scale changes to comprehend the climatic emergencies and anthropogenic stress. Also, studies on 
Table 5 Water quality standards for aquatic biodiversity propagation

\begin{tabular}{|c|c|c|c|c|}
\hline Water variables & BIS & $\mathrm{CPCB}$ & EPA & Present study \\
\hline $\mathrm{pH}$ & $6.5-8.5$ & $6.5-8.5$ & $6-8.5$ & $7.50-7.67$ \\
\hline $\mathrm{DO}\left(\mathrm{mgl}^{-1}\right)$ & 4.0 & $\begin{array}{l}5.0 \text { or } 60 \% \text { saturation value, } \\
\text { whichever is higher }\end{array}$ & $>5.5$ & $4.69-5.97$ \\
\hline Phosphate $\left(\mathrm{mgl}^{-1}\right)$ & 0.1 & - & - & $2.64-4.0$ \\
\hline $\mathrm{BOD}_{3}\left(\mathrm{mgl}^{-1}\right)$ & - & $<3\left(20^{\circ} \mathrm{C}\right.$ for 5 days $)$ & - & $1.81-2.20$ \\
\hline $\operatorname{COD}\left(\mathrm{mgl}^{-1}\right)$ & - & $<10$ (Outdoor bathing) & & $17-23.93$ \\
\hline Turbidity (NTU) & 10 & 30 & $<50$ & $36.93-65$ \\
\hline Free ammonia (as $\mathrm{N}$ ) & - & 1.2 or less & - & - \\
\hline
\end{tabular}

$B I S$ Bureau of Indian Standards, $C P C B$ Central Pollution Control Board, India, EPA US Environmental Protection Agency anthropogenic interferences such as pollution, coastal development, destructive fishing, ferrying, overexploitation, etc., resulted in unique information that may provide mitigating measures to conserve biodiversity. Water quality criteria for wildlife propagation and fisheries need to be addressed for the sustenance of endemic biota inhabiting in the Sundarban Biosphere Reserve, which is also opined by many previous workers. Although the creek waters (Sundarbans) are impacted by various human-induced activities (such as fishing, irrigation, ferry service, boating and tourism), some water quality parameters are still well within the permissible limits, where it is suitable for bathing, aquatic biodiversity, fisheries and recreation purpose.

Acknowledgements The authors are grateful to the Director, School of Environmental Studies, Jadavpur University, Kolkata -700032, India for laboratory support to carry out the research work. The authors also acknowledge Mr. K. Lohith Kumar, Scientist, ICAR-Central Inland Fisheries Research Institute, Kolkata for the preparation of the map citing the sampling stations.

Author contributions SB: conceptualization, sample collection, interpretation of data, and manuscript preparation. PG: statistical analysis, interpretant of data, and manuscript preparation. SB: guidance, review and manuscript corrections. SD: statistical analysis, and manuscript preparation. SKD: manuscript preparation and corrections.

Funding No financial support received from any organization, as the work was under a part of Ph.D. research work.

\section{Declarations}

Conflict of interest The authors declare that they have no known competing financial interests or personal relationships that could have appeared to influence the work reported in this manuscript.

Ethical approval The authors declare that they have strictly followed all the rules and principles of ethical and professional conduct while completing the research work. No specific permission was required to collect the water samples at the study sites. Under this research no involvement of human and/ or animals.
Open Access This article is licensed under a Creative Commons Attribution 4.0 International License, which permits use, sharing, adaptation, distribution and reproduction in any medium or format, as long as you give appropriate credit to the original author(s) and the source, provide a link to the Creative Commons licence, and indicate if changes were made. The images or other third party material in this article are included in the article's Creative Commons licence, unless indicated otherwise in a credit line to the material. If material is not included in the article's Creative Commons licence and your intended use is not permitted by statutory regulation or exceeds the permitted use, you will need to obtain permission directly from the copyright holder. To view a copy of this licence, visit http://creativecommons.org/licenses/by/4.0/.

\section{References}

APHA (2005) In: Rice EW, Baird RB, Eaton AD, Clesceri LS (eds) Standard methods for the examination of water and Wastewater, 21 st edn. American Public Health Association (APHA), American Water Works Association (AWWA) and Water Environment Federation (WEF), Washington, DC, USA

Ansari KGMT, Bhadury P (2017) Occurrence of epibionts associated with meiofaunal basibionts from the world's largest mangrove ecosystem, the Sundarbans. Mar Biodivers 47(2):539-548

Arumugum S, Sigamani S, Samikannu M, Perumal M (2016) Assemblages of phytoplankton diversity in diferent zonation of Muthupet mangroves. Reg Stud Mar Sci 3:234-241

Bagchi KG (1972) The Bhagirathi-Hooghly Basin. Calcutta University Publication, Calcutta

Barakat A, Baghdadia ME, Raisa J, Aghezzafb B, Slassib M (2016) Assessment of spatial and seasonal water quality variation of Oum Er Rbia River (Morocco) using multivariate statistical techniques. Int Soil Water Conserv Res 4:284-292

Barletta M, Lima AR, Costa MF (2019) Distribution, sources and consequences of nutrients, persistent organic pollutants, metals and microplastics in South American estuaries. Sci Total Environ 651:1199-1218. https://doi.org/10.1016/j.scitotenv. 2018.09.276

Bhattacharya BD, Hwang JS, Sarkar SK, Rakhsit D, Murugan K, Tseng LC (2015) Community structure of mesozooplankton in coastal waters of Sundarban mangrove wetland, India: a multivariate approach. J Mar Sys 141:112-121

Bostanmaneshrad F, Partani S, Noori R, Hans-Peter N, Berndtsson R, Adamowski JF (2018) Relationship between water quality and macro-scale parameters (land use, erosion, geology, and population density) in the Siminehrood River Basin. Sci Total Environ 639:1588-1600

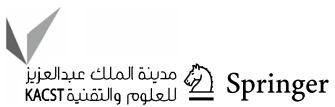


Brzezinski MA (1958) The Si:C:N ratio of marine diatoms: interspecific variability and the effect of some environmental variables. J Phycol 2:347-357

Chakraborti P (1995) Evolutionary history of the coastal quaternaries of the Bengal plain India. Proc INSA 61:343-354

Chang H (2008) Spatial analysis of water quality trends in the Han River basin, South Korea. Water Res 42:3285-3304

Chaudhuri K, Manna S, Sarma SK, Naskar P, Bhattacharyya S, Bhattacharyya M (2012) Physicochemical factors controlling water column metabolism in Sundarban estuary India. Aquat Biosyst $8: 26$

Chimwanza B, Mumba PP, Moyo BHZ, Kadewa W (2014) The impact of farming on river banks on water quality of the rivers. Int J Environ Sci Technol 2(4):353-358

Choudhury A, Bhadury P (2015) Relationship between N:P:Si ratio and phytoplankton community composition in a tropical estuarine mangrove ecosystem. Biogeosciences 12:2307-2355

Das GK (2012) Impact of water quality on the changing environmental scenario of Sunderbans. Reason 11:57-66

Debels P, Figueroa R, Urrutia R, Barra R, Niell X (2005) Evaluation of water quality in the Chillán River (Central Chile) using physicochemical parameters and a modified water quality index. Environ Monit Assess 110(1-3):301-322

Forina M, Armanino C, Raggio V (2002) Clustering with dendrograms on interpretation variables. Anal Chim Acta 454:13-19

Ghahremanzadeh H, Noori R, Baghvand A, Nasrabadi T (2018) Evaluating the main sources of groundwater pollution in the southern Tehran aquifer using principal component factor analysis. Environ Geochem Health 40:1317-1328

Gogoi P, Sinha A, Das Sarkar S, Chanu TN, Yadav AK, Koushlesh SK, Borah S, Das SK, Das BK (2019) Seasonal influence of physico-chemical parameters on phytoplankton diversity and assemblage pattern in Kailash Khal, a tropical wetland, Sundarbans India. Appl Water Sci 9:156

Gogoi P, Das SK, Das Sarkar S, Chanu TN, Manna RK, Sengupta A, Raman RK, Samanta S, Das BK (2020) Environmental factors driving phytoplankton assemblage pattern and diversity: insights from Sundarban eco-region. Ecohydrol Hydrobiol. https://doi.org/ 10.1016/j.ecohyd.2020.09.005

Gopal B, Chauhan M (2006) Biodiversity and its conservation in the Sundarban mangrove ecosystem. Aquat Sci 68(3):338-354

Hazra S, Ghosh T, Dasgupta R, Sen G (2002) Sea level and associated changes in the Sundarbans. Sci Cult 68(9-12):309-321

Helena B, Pardo R, Vega M, Barrado E, Fernandez JM, Fernandez L (2000) Temporal evolution of groundwater composition in an alluvial aquifer (Pisuerga River, Spain) by principal component analysis. Water Res 34:807-816

Hernández-Romero AH, Tovilla-Hernández C, Malo EA, BelloMendoza R. (2004) Water quality and presence of pesticides in a tropical coastal wetland in southern Mexico. Mar Pollut Bull 48(11-12):1130-1141

Karuppasamy PK, Perumal P (2000) Biodiversity of zooplankton in Pichavaram mangroves, South India. Adv Biosci 19:23-32

Khan MYA, Gani KM, Chakrapani GJ (2016) Assessment of surface water quality and its spatial variation. A case study of Ramganga River, Ganga Basin India. Arab J Geosci 9(1):1-9

Kumar M, Ramanathan A, Rao MS, Kumar B (2006) Identification and evaluation of hydrogeochemical processes in the groundwater environment of Delhi India. Environ Geol 50:1025-1039

Kumarasamy P, James RA, Dahms HU, Byeon CW, Ramesh R (2014) Multivariate water quality assessment from the Tamiraparani river basin Southern India. Environ Earth Sci 71(5):2441-2451

Levinton JS (2001) Marine biology. Oxford Univer Press, New York, p 560

Liu Y, Theller LO, Pijanowski BC, Engel BA (2016) Optimal selection and placement of green infrastructure to reduce impacts of land use change and climate change on hydrology and water quality: an application to the Trail Creek Watershed Indiana. Sci Total Environ 553:149-163

López-Lópezn JA, Mendiguchían C, García-Vargasn M, Morenon C (2014) Multi-way analysis for decadal pollution trends assessment: the Guadalquivir River estuary as a case study. Chemosphere 111:47-54

Majumdar RK, Mukherjee AL, Roy NG, Sarkar K, Das S (2002) Groundwater studies on south Sagar Island region, South 24-Parganas, West Bengal. In: Proceedings of the International Conference on Water Related Disasters, New Age International Publishers, Calcutta, India, pp 175-183

Mallin MA, Lewitus AJ (2004) The importance of tidal creek ecosystems. J Exp Mar Biol Ecol 2(298):145-149

Manna S, Chaudhuri K, Bhattacharyya S, Bhattacharyya M (2010) Dynamics of Sundarban estuarine ecosystem: eutrophication induced threat to mangroves. Saline Syst 6:8

Mitra A, Gangopadhyay A, Dube A, Schmidt ACK, Banerjee K (2009) Observed changes in water mass properties in the Indian Sundarbans (northwestern Bay of Bengal) during 1980-2007. Curr Sci 97:1145-1152

Mondal I, Bandyopadhyay J, Dhara S (2017) Detecting shoreline changing trends using principle component analysis in Sagar Island, West Bengal India. Spatial Inform Res 25(1):67-73

Murugan A, Ayyakkannu K (1991) Ecology of uppanar backwaters, Cuddalore: 1 physico-chemical parameters. Mahasagar 24(1):31-38

Noori R, Sabahi MS, Karbassi AR, Baghvand A, Taati Zadeh H (2010) Multivariate statistical analysis of surface water quality based on correlations and variations in the data set. Desalination 260:129-136

Noori R, Karbassi AR, Ashrafi Kh, Ardestani M, Mehrdadi N (2011) Development and application of reduced-order neural network model based on proper orthogonal decomposition for BOD5 monitoring: active and online prediction. Environ Progress Sustain Energy. https://doi.org/10.1002/ep.10611

Noori R, Karbassi A, Khakpour A, Shahbazbegian M, Khalf Badam HM, Vesali-Naseh M (2012) Chemometric analysis of surface water quality data: case study of the Gorganrud River Basin Iran. Environ Model Assess 17:411-420

Noori R, Safavi S, Nateghi Shahrokni SA (2013) A reduced-order adaptive neuro-fuzzy inference system model as a software sensor for rapid estimation of five-day biochemical oxygen demand. J Hydrol 495:175-185

Osibanjo O, Daso AP, Gbadebo AM (2011) Gbadebo AM (2011) The impact of industries on surface water quality of River Ona and River Alaro in Oluyole Industrial Estate, Ibadan Nigeria. Afr J Biotechnol 10(4):696-702

Otto M (1998) Multivariate methods. In: Kellner R, Mermet JM, Otto M, Widmer HM (eds) Analytical chemistry. Wiley-VCH, Weinheim, p 916

Paul AK, Bhandyopadhay MK (1987) Morphology of Sagar Island, a part of Ganga delta. J Geol Soc India 29:412-423

Rahaman SMB, Golder J, Rahaman MS, Hasanuzzaman AFM, Huq KA, Begum S, Islam SS, Bir J (2013) Spatial and temporal variations in phytoplankton abundance and species diversity in the Sundarbans mangrove forest of Bangladesh. J Mar Sci Res Dev 3(2):1-9

Rahaman SMB, Rahaman MS, Ghosh AK, Gain D, Biswas SK, Sarder L, Islam SS, Sayeed AB (2015) A spatial and seasonal pattern of water quality in the Sundarbans river systems of Bangladesh. J Coast Res. https://doi.org/10.2112/jcoastres-D13-00115.1 (Coconut Creek (Florida), ISSN 0749-0208)

Rajasegar M (2003) Physico-chemical characteristics of the Vellar estuary in relation to shrimp farming. J Environ Biol 24:95-101 
Rakshit D, Sarkar SK, Bhattacharya BD, Jonathan MP, Biswas JK, Mondal P, Mitra S (2015) Human-induced ecological changes in western part of Indian Sundarban Megadelta: a threat to ecosystem stability. Maine Pollut Bull 99:186-194

Ramakrishnan R, Perumal P, Santhanam P (1999) Spatio-temporal variations of hydrographical features in the Pichavaram mangroves and Mohi aqua farm, Southeast coast of India. In: Proceeding of international seminar on application with hydrogeochemistry. Annamalai University, Dept. of Geology, Annamalai University, Annamalai Nagar, Tamil Nadu, India, pp 197-203

Redfield AC (1958) The biological control of the chemical factors in the environment. Am Sci 46:205-222

Reghunath R, Murthy TR, Raghavan BR (2002) The utility of multivariate statistical techniques in hydro geochemical studies: an example from Karnataka, India. Water Res 36:2437-2442

Saliu JK, Ekpo MP (2006) Preliminary chemical and biological assessment of Ogbe Creek, Lagos, Nigeria, West Africa. App Ecol 9:12

Saravanakumar A, Rajkumar M, Thivakaran GA, Serebiah J (2008) Abundance and seasonal variations of phytoplankton in the creek waters of western mangrove of Kachchh-Gujarat. J Environ Biol 29(2):271-274

Sarkar SK and Bhattacharya BD (2010) Water quality analysis of the coastal regions of Sundarban Mangrove Wetland, India using multivariate statistical techniques. In: Sarkar SK (ed) Environmental management, p 258. ISBN 978-953-307-133-6

Sarkar SK, Singh BN, Choudhury A (1986) Compositions and variations in the abundance of zooplankton in the Hooghly estuary, West Bengal India. Proc Indian Acad Sci (Anim Sci) 95(2):125-134

Satpathy KK, Sahu G, Mohanty AK, Prasad MVR, Panigrahi RC (2009) Phytoplankton community structure and its variability during southeast monsoon transition in the coastal waters of Kalpakkam, East Coast of India. Int J Oceans Oceanogr 3(1):43-74

Şener Ş, Şener E, Davraz A (2017) Evaluation of water quality using water quality index (WQI) method and GIS in Aksu River (SWTurkey). Sci Total Environ 584-585(131-662):144

Sharma S (1996) Applied multivariate techniques. Wiley, New York

Sharma M, Kansal A, Jain S, Sharma P (2015) Application of multivariate statistical techniques in determining the spatial temporal water quality variation of Ganga and Yamuna Rivers present in Uttarakhand State, India. Water Qual Expo Health 7(4):567-581

Shrestha S, Kazama F (2007) Assessment of surface water quality using multivariate statistical techniques: a case study of the Fuji river basin Japan. Environ Modell Softw 22(4):464-475
Simeonova P, Simeonov V, Andreev G (2003) Water quality study of the Struma River Basin, Bulgaria. Cent Eur J Chem 2:121-136

Singh KP, Malik A, Mohan D, Sinha S (2004) Multivariate statistical techniques for the evaluation of spatial and temporal variations in water quality of Gomti river (India) - a case study. Water Res 38:3980-3992

Sreelekshmi S, Nandan SB, Kaimal SV, Radhakrishnan CK, Suresh VR (2020) Mangrove species diversity, stand structure and zonation pattern in relation to environmental factors-A case study at Sundarban delta, east coast of India. Reg Stud Mar Sci $1: 35: 101111$

Vajravelu M, Martin Y, Ayyappan S, Mayakrishnan M (2018) Seasonal influence of physico-chemical parameters on phytoplankton diversity, community structure and abundance at Parangipettai coastal waters, Bay of Bengal, South East Coast of India. Oceanologia. https://doi.org/10.1016/j.oceano.2017.08.003

Vega M, Pardo R, Barrado E, Deban L (1998) Assessment of seasonal and polluting effects on the quality of river water by exploratory data analysis. Water Res 32(12):3581-3592

Vernberg FJ, Vernberg WB (2001) The Coastal Zone. University of South Carolina Press, Columbia, p 191

Wang XL, Lu YL, Han JY, He GZ, Wang TY (2007) Identification of anthropogenic influence on water quality of rivers in Taihu watershed. J Environ Sci 19:475-481

Wang X, Cai Q, Ye L, Qu X (2012) Evaluation of spatial and temporal variation in stream water by multivariate statistical techniques: a case study of the Xiangxi River basin China. Q Int 1:1-8

Wang YB, Liu CW, Liao PY, Lee JJ (2014) Spatial pattern assessment of river water quality: Implications of reducing the number of monitoring stations and chemical parameters. Environ Monit Assess 186(3):1781-1792

Willet P (1987) Similarity and clustering in chemical information systems. Research Studies Press Wiley, New York

Wunderlin DA, Diaz MP, Ame MV, Pesce SF, Hued AC, Bistoni MA (2001) Pattern recognition techniques for the evaluation of spatial and temporal variations in water quality. A case study: Suquia river basin (Cordoba, Argentina). Water Res 35:2881-2894

Zhao J, Fu G, Lei K, Li Y (2011) Multivariate analysis of surface water quality in the Three Gorges area of China and implications for water management. J Environ Sci 23(9):1460-1471

Publisher's Note Springer Nature remains neutral with regard to jurisdictional claims in published maps and institutional affiliations. 